\title{
Determination of biomass stock in a mixed plantation of Pinus taeda L. and Pinus elliottii Engelm.
}

Renata Reis de Carvalho ${ }^{1 *}$ Jonathan William Trautenmüller ${ }^{1}$ Sabrina Reis de Carvalho ${ }^{1}$ Sergio Costa Júnior ${ }^{1}$ Dimas Agostinho da Silva ${ }^{1}$ Afonso Figueiredo Filho ${ }^{2}$

${ }^{1}$ Universidade Federal do Paraná, Av. Pref. Lothário Meissner, 632, Jardim Botânico, Campus III, CEP 80210-170, Curitiba, PR, Brasil

${ }^{2}$ Universidade Estadual do Centro-Oeste, Rua Professora Maria Roza Zanon de Almeida Engenheiro , Gutierrez, CEP: 84505-677, Irati - PR, Brasil

\section{Original Article \\ *Corresponding author: jwtraute@hotmail.com}

Keywords:

Forest biomass,

Direct method,

Tree components,

Pinus spp.

Palavras-chave:

Biomassa florestal,

Método direto,

Componentes da biomassa,

Pinus spp.

Received in

2020/04/07

\section{Accepted on}

2021/06/28

Published in 2021/08/31

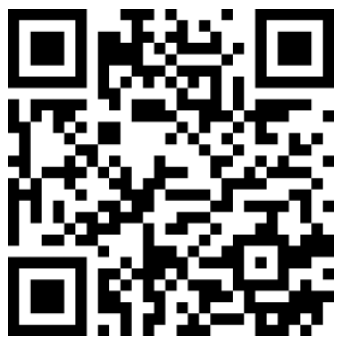

DOI:

http://dx.doi.org/10.34062/af s.v8i2.10129

\section{(cc) BY}

ABSTRACT: Mixed plantations, when well-managed, can be more efficient in the production of biomass and use of available resources, thus increasing the profits. The objectives of the present study were to quantify the biomass of a mixed plantation of Pinus taeda and Pinus elliottii using the direct method, to verify the allocation of biomass among different tree components, and to evaluate and compare the production of biomass per unit area of the mixed plantation and the two species studied. Through forest census performed in a 16-year-old mixed plantation covering 43.5 ha, the diametric distribution of the population was examined. Based on the diametric classes, 60 trees were randomly sampled using the direct method (30 trees of each studied species). The aerial biomass production of different tree components was evaluated and compared between the two studied species. Mixed plantation produced $171.5 \mathrm{tha}^{-1}$ of biomass, with the stem representing over $60 \%$ of total biomass. Biomass production of Pinus taeda was superior to that of Pinus elliottii. In turn, the biomass of branches significantly differed between the two species. Stand biomass production obtained using the stratified tree technique was lower than that obtained using the direct method. In the direct method, the biomass $\left(\mathrm{t} \mathrm{ha}^{-1}\right)$ of Pinus elliottii was higher, because its frequency in the central diameter class was greater in the forest census, with more individuals in the stand.

\section{Determinação do estoque de biomassa em uma plantação mista de Pinus taeda L. e Pinus elliottii Engelm}

RESUMO: As plantações mistas, quando bem administradas, podem ser mais eficientes na produção de biomassa e no uso dos recursos disponíveis, aumentando assim os lucros. Os objetivos do presente estudo foram quantificar a biomassa de uma plantação mista de Pinus taeda e Pinus elliottii pelo método direto, verificar a alocação de biomassa entre os diferentes componentes da árvore e avaliar e comparar a produção de biomassa por unidade de área da plantação mista e as duas espécies estudadas. Por meio do censo florestal realizado em uma plantação mista de 16 anos cobrindo 43,5 ha, a distribuição diamétrica da população foi examinada. Com base nas classes diamétricas, 60 árvores foram amostradas aleatoriamente pelo método direto (30 árvores de cada espécie estudada). A produção de biomassa aérea de diferentes componentes da árvore foi avaliada e comparada entre as duas espécies estudadas. O plantio misto produziu 171,5 tha1 de biomassa, com o fuste representando mais de $60 \%$ da biomassa total. A produção de biomassa de Pinus taeda foi superior à de Pinus elliottii. Por sua vez, a biomassa dos galhos diferiu significativamente entre as duas espécies. A produção de biomassa do povoamento obtida pela técnica de árvore estratificada foi inferior à obtida pelo método direto. No método direto, a biomassa $\left(\mathrm{t} \mathrm{ha}^{-1}\right) \mathrm{de}$ Pinus elliottii foi maior, pois sua frequência na classe de diâmetro central foi maior no censo florestal, com mais indivíduos no povoamento. 


\section{Introduction}

Rapidly growing plantations of Pinus taeda L. and Pinus elliottii Engelm. play pivotal roles in the forest sector as the source of wood, which finds multiple uses in several industries in this sector. Consequently, research projects related to appropriate plantation management have garnered much attention from forestry companies, as they allow for efficient and cost-effective planning and use of multiple wood products. In this way, the demands of the forestry market, aimed at obtaining high-quality wood with increased economic and industrial yield, can be met.

The objective of fast-growing plantations is to produce biomass and small-to-medium logs (Dobner Júnior et al. 2012). Therefore, prior studies of forest biomass are fundamental to estimate forest productivity, carbon fixation, and biomass energy (Zhao et al. 2016).

Furthermore, forest plantations are considered an alternative to achieve the global carbon balance, as they accumulate carbon both in biomass and soil. Therefore, forest biomass acts as a reservoir to balance the amount of carbon released into the environment, thus mitigating atmospheric pollution and, ultimately, climate change (Schikowski et al. 2014). Part of the forest biomass corresponds to carbon that can be converted to $\mathrm{CO}_{2}$ equivalents (Dallagnol et al. 2011). Thus, forest biomass must be accurately quantified (Schikowski et al. 2014).

Mixed plantations, when well-managed, can be highly efficient in the production of biomass and use of available resources, thus increasing the profits. Of note, forest biomass production is affected by multiple factors, such as the site quality, genetic ability of the species, and age and density of the plantation. In this context, numerous studies have evaluated biomass production of forests with diverse species and at different sites (Watzlawick et al. 2013; Lisboa et al. 2015; Lima et al. 2016; Silva et al. 2017; Sanquetta et al. 2019; Péllico Netto and Behling 2019) to gather data on forest plantations. Upon the identification of such factors, biomass production of plantations can be improved.

Measuring the biomass of all trees in a plantation is impractical given the constraints of time and resources (Watzlawick et al. 2013; Balbinot et al. 2019; Trautenmüller et al. 2019). In general, forest biomass is evaluated using four techniques, namely the medium tree (Trautenmüller et al. 2019), stratified tree (by diameter class), area unit (Balbinot et al. 2017; Trautenmüller et al. 2019), and regression (Balbinot et al. 2019) techniques; these techniques are further divided into direct (destructive) and indirect (non-destructive) methods. For any of the above biomass assessment techniques, a forest inventory must initially be performed.

Following forest inventory of the area, the evaluation technique is defined and then trees are selected. In the direct method, the selected trees are felled and then biomass is measured. However, despite its accuracy, the direct method is timeconsuming and costly, since forest biomass is determined through quantification and weighing (wet and dry) of different tree components (Qureshi et al. 2012; Balbinot et al. 2017; Trautenmüller et al. 2019).

Meanwhile, in the indirect method, biomass is estimated using regression models based on independent variables (diameter at breast height and total tree height) obtained from the forest inventory and dependent variables (dry matter weight of the total tree and its components) obtained using the direct method (Balbinot et al. 2019).

To this end, the objectives of the present study were to quantify biomass production of a mixed plantation of Pinus taeda and Pinus elliottii using the direct method, to verify the allocation of biomass among different tree components, and to evaluate and compare biomass production per unit area of the mixed plantation and the two species studied. Specifically, we tested the following hypotheses: (i) the two species in the mixed plantation show the same biomass allocation among their components and (ii) the two species produce the same amount of biomass per unit area.

\section{Material and Methods}

The study area belongs to Remasa Reflorestadora S.A., established in the municipality of Bituruna, state of Paraná $\left(26^{\circ} 07^{\prime} 00^{\prime \prime} \mathrm{S}\right.$, $\left.51^{\circ} 31^{\prime} 00^{\prime \prime} \mathrm{W}\right)$. According to the Köppen-Geiger classification, the climate of the region is humid subtropical, characterized as $\mathrm{Cfb}$ (Alvares et al. 2013).

The plot selected for the present study covered an area of $43.5 \mathrm{ha}$, and the target plantation was 16 years of age, destined for the final cut. The census of the study field was performed, and samples were defined for biomass measurement based on the diametric distribution of the field. A total of 60 trees in the mixed plantation of Pinus spp. were sampled (30 trees each of Pinus taeda and Pinus elliottii).

Initially, the diameter of the selected trees was measured at a height of $1.3 \mathrm{~m}$ from the ground (d), according to the diametric distribution of the forest census. Subsequently, the total height of the tree and biomass of different tree components were measured for each sample, following the recommendations of the Intergovernmental Panel on Climate Change (IPCC) (2006). After separation, all tree components (leaves, live branches, dry branches, and stems) were weighed to determine wet biomass.

In the field, small subsamples $(500 \mathrm{~g})$ of the acicular, live branch, and dry branch components were also weighed (wet) using a $0.01 \mathrm{~g}$ precision scale. Subsequently, all subsamples were sealed in 
plastic bags, suitably identified, and sent to the laboratory for the measurement of dry weight.

Leaves and branches from the top, middle, and base of the crown were also sampled. Moreover, four 5 -cm-thick stem disks with bark at the following positions were collected from each tree: $0.5 \mathrm{~m}$ above the ground, the point of $d$ measurement, $50 \%$ of the total height of the tree, and tip where the diameter with bark was $8 \mathrm{~cm}$ (height limit for commercial use). The samples were dried to a constant weight in an air circulation oven at $75^{\circ} \mathrm{C}$. The dry weight of each biomass component was calculated using the following formula:

\section{$\mathrm{BS}=\mathrm{BV} \times(1-\mathrm{TU})$}

where, $\mathrm{BS}$ is dry biomass (component) in $\mathrm{kg} ; B V$ is wet biomass (component) in $\mathrm{kg}$; and $T U$ is moisture content (component) in \%.

Furthermore, total biomass ( $\mathrm{kg}$ tree-1) was determined as the sum of dry biomass of all components.

For data analysis, a statistical model with completely randomized design was used in the scheme of subdivided plots. Factor A attributed to the plots was the species, and factor B attributed to the subplots was the biomass component. Random variables of the 30 trees, each considered a replicate, were determined.

Initially, assumptions for the analysis of variance (ANOVA) (normality and homogeneity) were tested. The biomass variable was subjected to $\log (\mathrm{X})$ transformation. The transformed data were subjected to ANOVA, and the effects of significant factors were compared using the Tukey test at 5\% significance level using $\mathrm{R}$ ( $\mathrm{R}$ Development Core Team 2017). For the variables diameter, total height, canopy biomass, stem biomass, and total biomass, only the effects of the species were compared using unpaired t-test at 5\% significance level.

\section{Results and discussion}

The biometric characterization of the populations (43.5 ha) and samples of Pinus spp., Pinus taeda, and Pinus elliottii is presented in Table 1. The results of characterization of the populations and samples were comparable, and the forest census accounted for an average of 444.5 individuals per hectare.
Table 1. Biometric characterization of the populations (43.5 ha) and samples of Pinus spp., Pinus taeda, and Pinus elliottii in a 16-year-old mixed plantation located in the municipality of Bituruna, state of Paraná

\begin{tabular}{ccccc}
\hline Variable & Population & \multicolumn{3}{c}{ Sample } \\
\cline { 3 - 5 } & & $\begin{array}{c}\text { Pinus } \\
\text { spp. }\end{array}$ & $\begin{array}{c}\text { Pinus } \\
\text { taeda }\end{array}$ & $\begin{array}{c}\text { Pinus } \\
\text { elliottii }\end{array}$ \\
\hline $\bar{d}(\mathrm{~cm})$ & 29.1 & 30.0 & 33.5 & 25.6 \\
$\bar{h}(\mathrm{~m})$ & 18.3 & 18.4 & 19.4 & 17.1 \\
$\bar{v}\left(\mathrm{~m}^{3}\right)$ & 0.6245 & 0.6100 & 0.7890 & 0.4495 \\
$\mathrm{~N}^{\left(\mathrm{ha}^{-1}\right)}$ & 444.5 & - & - & - \\
$\bar{V}\left(\mathrm{~m}^{3} \mathrm{ha}^{-}\right.$ & 277.4 & - & - & - \\
$\left.{ }^{1}\right)$ & & & & \\
\hline
\end{tabular}

$\bar{d}=$ Average diameter at breast height $\bar{h}=$ average total height; $\bar{v}=$ average individual volume; $\mathrm{N}=$ number of individuals per hectare; $\bar{V}=$ volume per unit area.

Diameter at breast height differed between Pinus taeda and Pinus elliottii (33.5 and $25.6 \mathrm{~cm}$, respectively), with the former presenting $7.9 \mathrm{~cm}$ greater diameter than the latter under the same environmental conditions and forestry management. Consistently, the height and volume of Pinus taeda were higher ( $2.3 \mathrm{~m}$ and $0.3395 \mathrm{~m} 3$, respectively). In single-species plantations, Chmura et al. (2007) reported that Pinus taeda presented higher diameter, height, and volume than Pinus elliottii. The authors attributed this superior performance of Pinus taeda to the favorable edaphoclimatic conditions of the area, particularly high soil moisture content and light availability.

According to Binkley et al. (2013) and Campoe et al. (2013), the higher productivity of pine plantations with greater height and diameter can be attributed to their higher efficiency to absorb and use the resources available at the site, resulting in a greater capacity to convert these resource into biomass and assimilate carbon. During the diametric classification of the samples obtained in the forest census, we observed heterogeneity between the studied species in terms of diametric amplitude. As such, the diametric amplitude of Pinus taeda was between 19 and $49 \mathrm{~cm}$ and that of Pinus elliottii was between 10 and $44 \mathrm{~cm}$.

Table 2 presents the average total biomass production and biomass production of each component $(\mathrm{kg} \cdot$ tree-1) of Pinus spp., Pinus taeda, and Pinus elliottii.

Table 2. Descriptive statistics of forest biomass production $\left(\mathrm{kg} \mathrm{tree}^{-1}\right)$ from a 16 -year-old mixed plantation of Pinus spp. located in the municipality of Bituruna, state of Paraná.

\begin{tabular}{cccccccccc}
\hline \multicolumn{10}{c}{ Biomass $\left(\mathrm{kg} \mathrm{ha}^{-1}\right)$} \\
\hline \multirow{4}{*}{ Pinus } & Statistics & Leaf & $\begin{array}{c}\text { Live } \\
\text { branch }\end{array}$ & $\begin{array}{c}\text { Dry } \\
\text { branch }\end{array}$ & Canopy & $\begin{array}{c}\text { Stem } \\
\text { Wood }\end{array}$ & $\begin{array}{c}\text { Stem } \\
\text { Bark }\end{array}$ & Stem & Total \\
\hline spp. & Maximum & 0.7 & 2.0 & 0.7 & 4.3 & 9.6 & 2.2 & 30.3 & 40.9 \\
& Average & 27.7 & 71.8 & 12.0 & 111.4 & 247.5 & 26.8 & 274.3 & 385.7 \\
& CV $(\%)$ & 89.9 & 89.9 & 90.2 & 84.0 & 70.3 & 62.5 & 62.8 & 67.0 \\
\hline
\end{tabular}


Carvalho et al.

\begin{tabular}{cccccccccc}
\hline \multirow{4}{*}{$P}$. & Minimum & 1.2 & 3.8 & 3.0 & 10.0 & 30.4 & 5.4 & 49.6 & 59.7 \\
taeda & Maximum & 79.2 & 255.7 & 42.0 & 327.8 & 605.5 & 83.3 & 624.0 & 951.8 \\
& Average & 27.4 & 92.8 & 17.4 & 137.7 & 286.5 & 27.4 & 304.5 & 442.2 \\
& CV (\%) & 79.2 & 76.4 & 69.5 & 72.3 & 55.2 & 57.6 & 50.5 & 56.2 \\
\hline \multirow{3}{*}{ P. } & Minimum & 0.7 & 2.0 & 0.7 & 4.3 & 9.6 & 2.2 & 30.3 & 40.9 \\
elliottii & Maximum & 101.2 & 197.8 & 20.0 & 323.7 & 655.9 & 55.9 & 660.5 & 858.4 \\
& Average & 27.9 & 49.9 & 6.4 & 84.2 & 216.7 & 26.1 & 242.9 & 327.1 \\
& CV (\%) & 101.0 & 99.4 & 80.9 & 99.0 & 88.4 & 84.3 & 82.3 & 83.4 \\
\hline
\end{tabular}

Canopy = leaf + live branches + dry branches; stem = stem wood + stem bark; CV\% = coefficient of variation.

The studied species showed great variation in biomass $\left(\mathrm{kg}\right.$ tree $\left.\mathrm{e}^{-1}\right)$, mainly in terms of the acicular and branch components. Disregarding thinning, the average total biomass for Pinus spp., Pinus taeda, and Pinus elliottii was $385.5,442.2$, and $327.1 \mathrm{~kg}$ tree $^{-1}$, respectively, indicating a production differential of $115 \mathrm{~kg}$ tree ${ }^{-1}$. Table 3 presents the results of analysis of variance of total biomass production $\left(\mathrm{kg} \mathrm{ha}^{-1}\right)$ and comparison of means using Tukey's test.

Table 3. Results of analysis of variance of the biomass production of Pinus elliottii and Pinus taeda and the comparison of their means in a 16-year-old mixed plantation in the municipality of Bituruna, state of Paraná

\begin{tabular}{|c|c|c|c|c|c|c|}
\hline \multicolumn{3}{|c|}{ Variation source } & \multicolumn{2}{|c|}{ Degrees of freedom } & \multicolumn{2}{|c|}{ Mean squared } \\
\hline \multicolumn{3}{|c|}{ Species } & \multicolumn{2}{|c|}{1} & \multicolumn{2}{|c|}{$5.46^{*}$} \\
\hline \multicolumn{3}{|c|}{ Component } & \multicolumn{2}{|c|}{5} & \multicolumn{2}{|c|}{$22.70 *$} \\
\hline \multicolumn{3}{|c|}{ Species $\times$ Component } & \multicolumn{2}{|c|}{5} & \multicolumn{2}{|c|}{$0.15^{\mathrm{ns}}$} \\
\hline \multicolumn{3}{|c|}{ Total } & \multicolumn{2}{|c|}{347} & & \\
\hline \multicolumn{3}{|c|}{ Coefficient of determination } & & & \multicolumn{2}{|c|}{0.77} \\
\hline \multicolumn{3}{|c|}{ Coefficient of variation $(\%)$} & & & \multicolumn{2}{|c|}{22.61} \\
\hline \multirow{2}{*}{ Species } & \multicolumn{6}{|c|}{ Biomass components $\left(\mathrm{kg}\right.$ tree $\left.^{-1}\right)$} \\
\hline & Leaf & Live branch & Dry branch & Stem wood & Stem bark & Total \\
\hline Pinus elliottii & $1.14^{\mathrm{aD}}$ & $1.45^{\mathrm{bC}}$ & $0.66^{\mathrm{bE}}$ & $2.10^{\mathrm{bB}}$ & $1.26^{\mathrm{aCD}}$ & $2.31^{\mathrm{bA}}$ \\
\hline Pinus taeda & $1.27^{\mathrm{aD}}$ & $1.81^{\mathrm{aC}}$ & $1.00^{\mathrm{aE}}$ & $2.39^{\mathrm{aB}}$ & $1.37^{\mathrm{aD}}$ & $2.60^{\mathrm{aA}}$ \\
\hline
\end{tabular}

Means followed by the same lowercase letters in the columns do not differ between species, and means followed by the same uppercase letters in the columns do not differ among biomass components at 5\% probability level according to Tukey's test. *significant at $5 \%$ probability level; ${ }^{\mathrm{ns}}$ not significant.

There were significant differences in wet mass, dry mass, and stem wood biomass between the species. Pinus taeda showed the highest values of percentage biomass allocation to different components. In general, the highest amount of biomass was allocated to the stem wood and live branch components. Table 4 presents the results of unpaired $t$-test of variables at $5 \%$ significance level.

Table 4. Results of $t$-test for the comparison of the mean diameter at breast height, total height, crown biomass, stem biomass, and total biomass in a 16year-old mixed plantation of Pinus spp. in the municipality of Bituruna, state of Paraná

\begin{tabular}{|c|c|c|c|}
\hline \multicolumn{2}{|c|}{ Variables } & \multicolumn{2}{|c|}{$t$-test } \\
\hline \multicolumn{2}{|c|}{$d(\mathrm{~cm})$} & \multicolumn{2}{|c|}{$2.46^{*}$} \\
\hline \multicolumn{2}{|c|}{$h(\mathrm{~m})$} & \multicolumn{2}{|c|}{$3.04 *$} \\
\hline \multicolumn{2}{|c|}{$\mathrm{BC}\left(\mathrm{kg}\right.$ tree $\left.^{-1}\right)$} & \multicolumn{2}{|c|}{$1.96^{*}$} \\
\hline \multicolumn{2}{|c|}{$\mathrm{BF}\left(\mathrm{kg}\right.$ tree $\left.^{-1}\right)$} & \multicolumn{2}{|c|}{$1.69^{\mathrm{ns}}$} \\
\hline $\mathrm{BT}(\mathrm{kg}$ & $\left.\mathrm{e}^{-1}\right)$ & \multicolumn{2}{|c|}{$1.48^{\mathrm{ns}}$} \\
\hline \multicolumn{4}{|c|}{ Comparison of averages } \\
\hline Species & $d$ & $h$ & $\mathrm{BC}$ \\
\hline $\begin{array}{l}\text { Pinus } \\
\text { elliottii }\end{array}$ & $25.57^{\mathrm{b}}$ & $17.13^{b}$ & $84.19^{\mathrm{b}}$ \\
\hline Pinus taeda & $33.53^{\mathrm{a}}$ & $19.43^{\mathrm{a}}$ & $137.73^{\mathrm{a}}$ \\
\hline
\end{tabular}

$d$ : diameter at breast height; $h$ : total height; BC: canopy biomass; BF: stem biomass; BT: total biomass; *significant at the 5\% probability level; ${ }^{\text {ns }}$ not significant. Means followed by the same lowercase letters in the columns do not differ between species at $5 \%$ probability level according to Tukey's test.

Stem biomass and total biomass did not differ significantly between the two species, but the diameter at breast height, total height, and canopy biomass were significantly different at 5\% probability level ( $t$-test). Overall, Pinus taeda was statistically superior to Pinus elliottii. According to Shimizu (2008), Pinus elliottii is characterized by high tolerance of humid soils. In addition, this species has originated from an environment with characteristics similar to those of tropical regions. Thus, in colder and wetter places, such as the study region, Pinus elliottii shows lower growth and produces less biomass than Pinus taeda. The allocation of biomass to different components in Pinus spp. observed in the present study was consistent with the trends reported in literature, with the greatest allocation to stem wood, followed by branches and leaves. Table 5 presents the percentage of total biomass allocated to each component. 
Table 5. Total biomass $\left(\mathrm{kg}\right.$ tree $\left.^{-1}\right)$ and biomass allocated to each component, disregarding thinning, in a 16-yearold pine plantation in the municipality of Bituruna, state of Paraná

\begin{tabular}{ccccccc}
\hline \multirow{2}{*}{ Component } & \multicolumn{2}{c}{ Average biomass $\left(\mathrm{kg} \mathrm{tree}^{-1}\right)$} & \multicolumn{3}{c}{$\%$} \\
\cline { 2 - 7 } & Pinus spp. & Pinus taeda & Pinus elliottii & Pinus spp. & Pinus taeda Pinus elliottii \\
\hline Leaf & 27.7 & 27.4 & 27.9 & 7.2 & 6.2 & 8.5 \\
Live branch & 71.8 & 92.8 & 49.9 & 18.6 & 21.0 & 15.3 \\
Dry branch & 12 & 17.4 & 6.4 & 3.1 & 3.9 & 2.0 \\
Canopy & 11.4 & 137.7 & 84.2 & 28.9 & 31.1 & 25.7 \\
Stem wood & 247.5 & 286.5 & 216.7 & 64.2 & 62.7 & 66.3 \\
Stem bark & 26.8 & 27.4 & 26.1 & 6.9 & 6.2 & 8.0 \\
Stem & 274.3 & 304.5 & 242.9 & 71.1 & 68.9 & 74.3 \\
\hline Total & 385.7 & 442.2 & 327.1 & 100 & 100 & 100 \\
\hline
\end{tabular}

In the canopy, the highest percentage of biomass was allocated to live branches, and this value was the highest for Pinus taeda. This result corroborates the observation of Shimizu et al. (2008) that Pinus taeda often bears more thick branches than Pinus elliottii.

Furthermore, crown biomass accounted for $26 \%$ and $31 \%$ total biomass in Pinus elliottii and Pinus taeda, respectively. The lowest proportion of biomass was allocated to the leaves and bark, with values being slightly higher in Pinus elliottii $(8.5 \%$ and $8.0 \%$, respectively) than in Pinus taeda (6.2\% both). As expected, in both species, the biomass of stem was superior to that of the other components. Biomass of all components, except leaves, was higher in Pinus taeda than in Pinus elliottii. According to Aguiar et al. (2014), Pinus elliottii is characterized by denser and longer leaves than Pinus taeda. In the studied mixed plantation, leaf biomass was slightly higher in Pinus elliottii.

There is often wide variability in the proportion of biomass allocated to the bark and branches, which renders the estimation of biomass production of these components difficult, and biomass allocation to these components tends to decrease with stem growth (Schikowski et al. 2013). Stem wood biomass was $286.5 \mathrm{~kg}$ tree $\mathrm{e}^{-1}$ for Pinus taeda and $216.7 \mathrm{~kg}$ tree ${ }^{-1}$ for Pinus elliottii. According to Aguiar et al. (2014), Pinus taeda typically produces high stem biomass. According to Shimizu (2008) and Aguiar et al. (2011, 2014), due to genetic characteristics, Pinus elliottii has lower productivity than Pinus taeda, mainly in terms of volume and number of branches. By assessing wood production in Pinus taeda plantations in Southeast USA, Ward et al. (2015) showed that water stress reduced the biomass production of plantations. Table 6 presents biomass produced per hectare in the mixed pine plantation in the present study.

Table 6. Total biomass $\left(\mathrm{t} \mathrm{ha}^{-1}\right)$ of a mixed plantation of Pinus taeda and Pinus elliottii, disregarding thinning

\begin{tabular}{|c|c|c|c|c|c|c|}
\hline \multirow[b]{2}{*}{ Component } & \multicolumn{3}{|c|}{ Biomass $\left(\mathrm{t} \mathrm{ha}^{-1}\right)$} & \multicolumn{3}{|c|}{$\%$} \\
\hline & $\begin{array}{c}\text { Pinus } \\
\text { spp. }\end{array}$ & $\begin{array}{l}\text { Pinus } \\
\text { taeda e }\end{array}$ & $\begin{array}{l}\text { Pinus } \\
\text { elliottii }\end{array}$ & $\begin{array}{c}\text { Pinus } \\
\text { spp. }\end{array}$ & $\begin{array}{l}\text { Pinus } \\
\text { taeda }\end{array}$ & $\begin{array}{c}\text { Pinus } \\
\text { elliottii }\end{array}$ \\
\hline Lea & 12.3 & 12.2 & 12.4 & 6.9 & 6.2 & 8.5 \\
\hline Live br: & 31.9 & 41.2 & 22.2 & 18.7 & 21 & 15.3 \\
\hline Dry branch & 5.3 & 7.7 & 2.8 & 2.5 & 3.9 & 2.0 \\
\hline Canol & 49.5 & 61.2 & 37.4 & 28.1 & 31.1 & 25.7 \\
\hline Stem wood & 110.0 & 127.3 & 96.3 & 65.2 & 64.8 & 66.2 \\
\hline
\end{tabular}

\begin{tabular}{ccccccc} 
Stem bark & 11.9 & 12.2 & 11.6 & 6.7 & 6.2 & 8.0 \\
Stem & 121.9 & 135.3 & 107.9 & 71.9 & 68.9 & 74.3 \\
\hline Total & 171.5 & 200.6 & 145.4 & 100 & 100 & 100 \\
\hline
\end{tabular}

In the studied mixed plantation, the average production per hectare was 171.5 tons of aboveground biomass, with the biomass production of the stem being the highest $(71.1 \%)$ and that of dry branches being the lowest (3.1\%). Similarly, by evaluating the biomass production of Pinus taeda and Pinus elliottii in plantations aged 2-22 years, established in Paraná, Schikowski et al. (2013) found that up to 5 years of age, the leaves accounted for $16 \%$ of total biomass, but this proportion decreased with advancing age, dropping to $7 \%$ by the age of 10 years and $2 \%$ after the age of 20 years. Moreover, in older plantations, aged 10 years and above, wood accounted for over $60 \%$ of total biomass, representing the largest share of total biomass. The biomass production $\left(\mathrm{t} \mathrm{ha}^{-1}\right)$ of the mixed plantation, disregarding thinning, in the present study was similar to the previously reported values for the same species but of different ages (Table 7

Table 7. Estimates of total biomass production ( $\mathrm{t}$ ha 1) from forests reported in literature on Pinus taeda and Pinus elliottii

\begin{tabular}{|c|c|c|c|c|}
\hline Study & Species & $\begin{array}{c}\text { Age } \\
\text { (years) }\end{array}$ & Site & $\begin{array}{c}\text { Total biomass }(\mathrm{t} \\
\left.\mathrm{ha}^{-1}\right)\end{array}$ \\
\hline Lisa et al. (2008) & $\begin{array}{l}\text { Pinus } \\
\text { taeda }\end{array}$ & 11 & EUA & 172.0 \\
\hline $\begin{array}{l}\text { Oliveira et al. } \\
\text { (2016) }\end{array}$ & $\begin{array}{l}\text { Pinus } \\
\text { elliottii }\end{array}$ & 12 & RS & 215.7 \\
\hline $\begin{array}{l}\text { Watzlawick and } \\
\text { Caldeira (2004) }\end{array}$ & $\begin{array}{l}\text { Pinus } \\
\text { taeda }\end{array}$ & 14 & PR & 171.7 \\
\hline $\begin{array}{l}\text { Zhao et al. } \\
\text { (2016) }\end{array}$ & $\begin{array}{l}\text { Pinus } \\
\text { taeda }\end{array}$ & 15 & EUA & 234.0 \\
\hline $\begin{array}{l}\text { Watzlawick and } \\
\text { Caldeira (2004) }\end{array}$ & $\begin{array}{l}\text { Pinus } \\
\text { taeda }\end{array}$ & 16 & PR & 122.0 \\
\hline $\begin{array}{l}\text { Balbinot et al. } \\
\qquad(2008)\end{array}$ & $\begin{array}{l}\text { Pinus } \\
\text { spp. }\end{array}$ & 16 & PR & 198.5 \\
\hline $\begin{array}{l}\text { Sixel et al. } \\
\quad(2015)\end{array}$ & $\begin{array}{l}\text { Pinus } \\
\text { taeda }\end{array}$ & 16 & $\mathrm{SC}$ & 259.0 \\
\hline \multicolumn{2}{|c|}{$\begin{array}{l}\text { Watzlawick andPinus } \\
\text { Caldeira (2004) taeda }\end{array}$} & 19 & PR & 102.2 \\
\hline \multicolumn{2}{|c|}{$\begin{array}{llr}\text { Giongo } & \text { et } & \text { al.Pinus } \\
\text { (2011) } & & \text { elliottii }\end{array}$} & 23 & PR & 161.3 \\
\hline
\end{tabular}


Carvalho et al.

\begin{tabular}{|c|c|c|c|c|}
\hline $\begin{array}{c}\text { Schumacher et } \\
\text { al. (2013) }\end{array}$ & $\begin{array}{l}\text { Pinus } \\
\text { taeda }\end{array}$ & 27 & $\mathrm{RS}$ & 266.0 \\
\hline \multirow{3}{*}{ Present Study } & $\begin{array}{l}\text { Pinus } \\
\text { spp. }\end{array}$ & \multirow{3}{*}{16} & \multirow{3}{*}{ PR } & 171.5 \\
\hline & $\begin{array}{l}\text { Pinus } \\
\text { taeda }\end{array}$ & & & 196.6 \\
\hline & $\begin{array}{l}\text { Pinus } \\
\text { elliottii }\end{array}$ & & & 145.4 \\
\hline
\end{tabular}

According to Sixel et al. (2015), the southern region of Brazil has conditions conducive to the rapid growth of pine plantations and, consequently, the production of biomass. However, according to Pedrosa et al. (2013), in addition to environmental conditions, variation in biomass production across species within the same population may be related to the origin of the species. Aguiar et al. (2014) and Shimizu (2008) reported higher biomass production of Pinus elliottii than of Pinus taeda when planted in low-altitude regions with moderate water deficit, primarily in the Cerrado region of northern Paraná, parts of the state of São Paulo, and southern
Brazilian coast.

In the present study, stem wood biomass production of Pinus spp. was $110 \mathrm{t} \mathrm{ha}^{-1}$. Giongo et al. (2011) reported a similar value $\left(131 \mathrm{t} \mathrm{ha}^{-1}\right)$ in a 23-year-old Pinus elliottii plantation in Paraná. Additionally, Sixel et al. (2015) reported wood biomass of $195 \mathrm{t} \mathrm{ha}^{-1}$ in a 16-year-old Pinus taeda plantation in the municipality of Otacílio Costa in the state of Santa Catarina; the authors reported that biomass allocation was in the order of wood $>$ bark $>$ branches > leaves. In a 27-year-old Pinus taeda plantation, Schumacher et al. (2013) observed biomass allocation in the order of wood $>$ branches $>$ bark $>$ leaves. Likewise, stem and crown biomass in the studied 16-year-old mixed plantation was similar to the values reported in previous studies on the same genus. Moreover, the proportion of biomass allocated was in the order of wood > branches $>$ leaves $>$ bark. Biomass production based on the stratified tree technique is presented in Table 8.

Table 8. Average biomass per hectare according to diametric classes $(d)$ in the forest census of a 16-year-old mixed plantation located in the municipality of Bituruna, state of Paraná.

\begin{tabular}{|c|c|c|c|c|c|}
\hline \multicolumn{6}{|c|}{ Pinus spp. } \\
\hline $\begin{array}{c}\text { Diametric class } \\
(\mathrm{cm})\end{array}$ & $\begin{array}{c}\text { Census } \\
\text { frequencies }\end{array}$ & $\begin{array}{l}\text { Frequencies } \\
\text { per hectare }\end{array}$ & $\begin{array}{c}\text { Tree frequencies } \\
(\text { sampled } *)\end{array}$ & 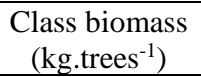 & Biomass (t.ha $\left.{ }^{-1}\right)$ \\
\hline $6.5-11.49$ & 23 & 0.53 & 4 & 53.6 & 0.04 \\
\hline $11.5-16.49$ & 155 & 3.56 & 4 & 58.2 & 0.2 \\
\hline $16.5-21.49$ & 741 & 17.00 & 8 & 135.8 & 2.3 \\
\hline $21.5-26.49$ & 4544 & 104.27 & 7 & 237.7 & 24.8 \\
\hline 26.5-31.49 & 8471 & 194.38 & 10 & 338.0 & 65.7 \\
\hline $31.5-36.49$ & 4144 & 95.09 & 9 & 456.6 & 43.4 \\
\hline $36.5-41.49$ & 989 & 22.69 & 7 & 636.2 & 14.5 \\
\hline $41.5-46.49$ & 234 & 5.37 & 7 & 711.6 & 3.8 \\
\hline $46.5-51.49$ & 58 & 1.33 & 4 & 828.4 & 1.1 \\
\hline $51.5-56.49$ & 12 & 0.28 & - & - & - \\
\hline Total & 19,371 & 444.50 & 60 & $3,456.6$ & 155.8 \\
\hline \multicolumn{6}{|c|}{ Pinus taeda } \\
\hline $6.5-11.49$ & 23 & 0.53 & - & - & - \\
\hline $11.5-16.49$ & 155 & 3.56 & - & - & - \\
\hline $16.5-21.49$ & 741 & 17.00 & 4 & 114.6 & 1.9 \\
\hline $21.5-26.49$ & 4544 & 104.27 & 4 & 284.4 & 29.6 \\
\hline 26.5-31.49 & 8471 & 194.38 & 6 & 309.8 & 60.3 \\
\hline $31.5-36.49$ & 4144 & 95.09 & 4 & 438.5 & 41.7 \\
\hline $36.5-41.49$ & 989 & 22.69 & 4 & 612.9 & 13.9 \\
\hline $41.5-46.49$ & 234 & 5.37 & 4 & 664.0 & 3.6 \\
\hline $46.5-51.49$ & 58 & 1.33 & 4 & 828.5 & 1.1 \\
\hline $51.5-56.49$ & 12 & 0.28 & - & - & - \\
\hline Total & 19.371 & 444,50 & 30 & $3,252.5$ & 152.1 \\
\hline \multicolumn{6}{|c|}{ Pinus elliottii } \\
\hline $6.5-11.49$ & 23 & 0.53 & 4 & 53.6 & 0.03 \\
\hline $11.5-16.49$ & 155 & 3.56 & 4 & 58.2 & 0.2 \\
\hline $16.5-21.49$ & 741 & 17.00 & 4 & 157.1 & 2.7 \\
\hline $21.5-26.49$ & 4544 & 104.27 & 3 & 191.2 & 19.8 \\
\hline 26.5-31.49 & 8471 & 194.38 & 4 & 366.2 & 71.2 \\
\hline $31.5-36.49$ & 4144 & 95.09 & 5 & 474.9 & 45.2 \\
\hline $36.5-41.49$ & 989 & 22.69 & 3 & 659.6 & 15.0 \\
\hline $41.5-46.49$ & 234 & 5.37 & 3 & 759.4 & 4.1 \\
\hline $46.5-51.49$ & 58 & 1.33 & - & - & - \\
\hline $51.5-56.49$ & 12 & 0.28 & - & - & - \\
\hline Total & 19,371 & 444.50 & 30 & $2,720.3$ & 158.2 \\
\hline
\end{tabular}


Using the stratified tree technique, the aerial biomass production of the studied mixed Pinus spp. plantation was $155.84 \mathrm{t} \mathrm{ha}^{-1}$. As expected, the average biomass by diametric class $\left(\mathrm{kg}^{\text {tree }}{ }^{-1}\right)$ for Pinus taeda was higher than that for Pinus elliottii, since the sampled Pinus taeda trees predominated the upper diametric classes. However, the average biomass $\left(\mathrm{t} \mathrm{ha}^{-1}\right)$ of Pinus elliottii $\left(158.2 \mathrm{t} \mathrm{ha}^{-1}\right)$ was higher than that of Pinus taeda (152.1 tha-1), perhaps because of the greater frequency of individuals of the former species in the central diametric classes in census.

\section{Conclusions}

Under the same edaphoclimatic conditions and forestry management, the direct method revealed heterogeneity in aerial biomass production between Pinus taeda and Pinus elliottii. Specifically, Pinus taeda produced higher average biomass than Pinus elliottii, although the difference between the species was not significant. The biomass production of branches significantly differed between the studied species, with Pinus taeda achieving the highest production.

Biomass estimated using the stratified tree technique was lower than that estimated using the direct method. The direct method revealed higher frequency of individuals in the forest census and greater production of biomass in the central diametric classes.

\section{References}

Aguiar AV, Sousa VA, Shimizu JY (2014) Cultivo de Pinus. Embrapa Florestas, Sistemas de Produção, $2^{\mathrm{a}}$ edição.

Aguiar AV, Sousa VA, Fritzsons E, Pinto Junior JE (2011) Programa de melhoramento de Pinus da Embrapa Florestas. Documento 233. Embrapa Florestas,Colombo-Paraná.

Alvares CA, Stape JL, Sentelhas PC, Gonçalves JLM, Sparovek G (2013) Köppen's climate classification map for Brazil. Meteorologische Zeitschrift, 22(6): 711-728.

Balbinot R, Trautenmüller JW, Caron BO, Borella J, Costa Júnior S, Breunig FM (2017) Vertical distribution of aboveground biomassin a seasonal deciduous forest. Revista Brasileira de Ciências Agrárias, 12(3): 361-365.

Balbinot R, Trautenmüller JW, Caron BO, Breunig FM, Borella J, Carvalho RR (2019) Modelling of allometric equations for biomass estimate in deciduous forest. Floresta, 49(1): 143-154.

Balbinot R, Valério AF, Sanquetta CR, Caldeira MVW, Silvestre R (2008) Estoque de carbono em plantações de Pinus spp. em diferentes idades no sul do Estado do Paraná. Floresta, 38(2): 317-324.

Binkley D, Campoe OC, Gspaltl M, Forrester DI (2013) Light absorption and use efficiency in forests: why patterns differ for tree and stands. Forest Ecology and Management, 288: 5-13.

Campoe OC, Stape JL, Albaugh TJ, Allen HL, Fox TR, Rubilar R, Binkley D (2013) Fertilization and irrigation effects on tree level aboveground net primary production, light interception and light use efficiency in a loblolly pine plantation. Forest Ecology and Management, 288: 43-48.

Chmura DJ, Rahman MS, Tjoelker MG (2007) Crown structure and biomass allocation patterns modulate aboveground productivity in young loblolly pine and slash pine. Forest Ecology and Management, 243: 219-230.

Dallagnol FS, Mognon F, Sanquetta CR, Corte APD (2011) Teores de carbono de cinco espécies florestais e seus componentes. Floresta e Ambiente, 18(4): 410-416.

Giongo M, Silva DB, Koehler HS, Marchetti M (2011) Inventário de biomassa em um plantio de Pinus elliottii Engelm. aos 23 anos de idade. Journal of Biotechnology and Biodiversity, 2(3): 81-86.

IPCC - Intergovernmental Panel On Climate Change (IPCC) (2006) Guidelines for National Greenhouse Gas Inventories. No site: www.ipcc.ch. Guia de Boas Práticas.

Li X, Yi MJ, Filho Y, Park PS, Lee KH, Son YM, Kim SH, Jeong MJ (2010) Biomass and carbon storage in an age-sequence of korean pine (Pinus koraiensis) plantation forests in Central Korea. Journal of Plant Biology, 54(1): 33-42.

Lima MCD, Barreto-Garcia PAB, Sanquetta CR, Novaes AB, Melo LC (2016) Biomass and carbon stock from Pinus caribaea var. hondurensis under homogenous stands in southwest Bahia, Brazil. Ciência Rural, 46(6): 957-962.

Lisboa GS, Lanzarin K, Lira DFS, Pescador CMM, Watzlawick LF, Valério AF (2015) Quantificação da biomassa em plantios dePinus elliottii Engelm. em Clevelândia - PR. Revista Instituto Florestal, 27(1): 103-115.

Lisa J, Samuelson JB, Chris Maier TA, Stokes KJ, Michael K (2008) Growth and physiology of loblolly pine in response to long-term resource management: defining growth potential in the southern United States. Canadian Journal of Forest Research, 38(4): 721-732. 
Oliveira M, Ril FL, Peretti C, Capellesso ES, Sausen TL, Budke JC (2016) Biomassa e estoques de carbono em diferentes sistemas florestais no Sul do Brasil. Perspectiva, 40(149): 09-20.

Pedrosa TD, Mascarenhas ARP, Melo RR, Stangerlin DM (2013) Estimativa da biomassa em um plantio de Eucalyptus grandis na região CentroOeste. Scientia Plena, 9(5): 1-7.

Péllico Netto S, Behling A (2019) Additivity of tree biomass components using ratio estimate. Anais da Academia Brasileira de Ciências, 91: e2018027231.

Qureshi A, Dobriyal P, Badola R, Hussain SA (2012) A review of protocols used for assessment of carbon stock in forested landscapes. Environmental Science \& Police, 16: 81-89.

R Development Core Team (2017) R: A language and environment for statistical computing. $\mathrm{R}$ Foundation for Statistical Computing. Vienna, Austria.

Sanquetta CR, Minatti M, Costa Júnior S, Trautenmüller JW, Corte APD (2019) Independent and simultaneous modeling of biomass and carbon of Elaeis guinean. Floresta, 49(3): 421-430.

Schikowski AB, Corte APD, Sanquetta CR, Maas GCB, Rodrigues AL (2014) Fator de expansão de biomassa e razão raízes-parte aérea para Populus sp. In: Sanquetta CR, Corte APD (ed) Atualidades em mensuração florestal, p. 170-173.

Schikowski AB, Corte APD, Sanquetta CR (2013) Modelagem do crescimento e de biomassa individual de Pinus. Pesquisa Florestal Brasileira, 33(75): 269-278.

Schumacher MV, Witschoreck R, Calil FN, Lopes VG (2013) Biomassa e nutrientes no corte raso de um povoamento de Pinus taeda L. de 27 anos de idade em Cambará do Sul - RS. Ciência Florestal, 23(2): 321-332.
Shimizu JY (2008) Pinus na silvicultura brasileira. Colombo: Embrapa Florestas, 223p.

Silva CA, Klauberg C, Hentz AMK, Carvalho SPC, Corte APD (2017) Predição da biomassa aérea em plantações de Pinus taeda L.por meio de dados LiDAR aerotransportado. Scientia Forestalis, 45(115): 527-259.

Sixel RMM, Arthur Junior JC, Gonçalves JLM, Alvares CA, Andrade GRP, Azevedo AC, Stahl J, Moreira AM (2015) Sustainability of wood productivity of Pinus taeda based on nutrient export and stocks in the biomass and in the soil. Revista Brasileira de Ciência do Solo, 39(5): 1416-1427.

Trautenmüller JW, Péllico Netto $\mathrm{S}$, Balbinot R, Corte APD, Borella J (2019) Path analysis applied to evaluation of biomass estimates in subtropical forests of Brazil. Floresta, 49(3): 587-596.

Ward EC, Domec JC, Laviner MA, Fox TR, Sun G, Mcnulty S, King J, Noormets A (2015) Fertilization intensifies drought stress: water use and stomatal conductance of Pinus taeda in a midrotation fertilization and through fall reduction experiment. Forest Ecology and Management, 355: 72-82.

Watzlawick LF, Caldeira MVW (2004) Estimativa de biomassa e carbono orgânico em povoamentos de Pinus taeda L. com diferentes idades. Biomassa \& Energia, 1(4): 371-380.

Watzlawick LF, Caldeira MVW, Godinho TO, Balbinot R, Trautenmüller JW (2013) Aboveground stock or biomass and organic carbon in stands of Pinus taeda L. Cerne, 19(3): 509-515.

Zhao D, Kane M, Teskey R, Fox TR, Albaugh T, Allen HL (2016) Maximum response of loblolly pine plantations to silvicultural management in the southern United States. Forest Ecology and Management, 375(1): 105-111. 